\title{
Digitalization of Economic Activity Management and Sustainable Enterprise's Development
}

\author{
Oksana Davydova, Nataliia Kashchena, Tetiana Staverska, Hanna Chmil
}

\begin{abstract}
Digital globalization and Ukrainian integration into the global economic space have speeded up digitalization and determined it as a driver of increased competitiveness, economic activity and sustainable development of economic entities. Steady modernization of existing and creation of new digital and information technologies necessitates changes in the format of business models of business entities, approaches to their management. Radical changes in the strategy of business development and enterprise management processes under the influence of digitalization in the near future will become necessary prerequisite of viability and development in the digital ecosystem "state - business - society". In view of this, the purpose of this work is determined as study of the world experience and prerequisites for the transition of enterprises to digital management and development of the reference model of the economic activity and enterprise development digitization management. The approach to the digitization of economic activity management and sustainable development of domestic enterprises is proposed in the work with taking into account the world experience of business administration digitalization. It is substantiated that the enterprise management digitalization requires the definition and rethinking of forms, trends, methods, technologies and digital engineering tools, innovation policy and corresponding corporate culture, communication mechanisms between all management units for quick implementation of changes. The results of the work prove that the implementation effectiveness of management actions and measures for enterprise management digitalization, its activity and development depends on the selected digital transformation technologies, the possibility of relevant data information arrays forming, their analytical processing and presentation for certain decisions making in real time. The reference digitalization model of economic activity management and enterprise development is elaborated; its distinctive feature is the integration of three platforms (information, analytical and management) in one management loop, which allows obtaining the synergistic effect of the management process digital transformation at all its levels. The practical implementation of the proposed digitalization model of economic activity management and sustainable development of

the enterprise allows gaining strategic benefits from business processes conversion and managing them into digital format, providing the management process optimization and the possibility of decisions making in real time.
\end{abstract}

Revised Version Manuscript Received on October 15, 2019.

Oksana Davydova, the Department of Hotel and Restaurant Business, Kharkiv State University of Food Technology and Trade, Kharkiv, Ukraine. (Email: davydova_oks@ukr.net)

Nataliia Kashchena, the Department of Finance, Analysis and Insurance, Kharkiv State University of Food Technology and Trade, Kharkiv, Ukraine. (Email: natakaschena@gmail.com)

Tetiana Staverska, the Department of Finance, Analysis and Insurance, Kharkiv State University of Food Technology and Trade, Kharkiv, Ukraine. (Email: staverskaya@gmail.com)

Hanna Chmil, the Department of Marketing and Commercial Activities, Kharkiv State University of Food Technology and Trade, Kharkiv, Ukraine. (Email: hannachmil@gmail.com)
Keywords: digitalization, digital transformation, management, economic activity, sustainable development, enterprise, business process, reference model of management digitalization.

\section{INTRODUCTION}

Digital globalization is characterized by the infinity and continuity of information, knowledge, ideas and innovation flows and activates transition of the global economy to the digital format with dominance of artificial intelligence, automation and digital platforms. The latest digital technologies allow to the state, business and the population more effectively interaction and provide the sustainable development goals achievement by penetrating all spheres of the society. Steady modernization of existing and creation of new digital and information technologies necessitates changes in the format of business models of business entities, approaches to their management. At present, radical changes of the business development strategy and processes under the influence of digitalization are objective reality for a minority of market participants. However, in the near future they will become necessary prerequisite of viability and development in the digital ecosystem «state - business - society». In view of this, it is the urgent need to research and adapt the world experience of business administration digitalization to the conditions of domestic enterprises functioning. It will not only gain the strategic benefits from conversion of business processes into digital formats, but also increase the efficiency of economic activity management and enterprise's sustainable development through management process optimization and the possibility of decisions making in real time.

\section{LITERATURE REVIEW}

The review of the scientific literature identifies active interest of domestic and foreign researchers in the problems of providing the enterprises' economic activity and their sustainable development under digital business transformation. The works of L. Andersson, D. Bonne, Dzh. Vesterman, O. Vyshnevskyi, A. Domanskyi, N. Kolin, A. Landie, L. Lihonenko, V. Liashenko, E. Makafi, P. Monen, L. Van der Kheide, A. Khripko and others are devoted to the problematic of the digital economy formation and conditions of business structures functioning in the new format [1-6]. The theoretical basis and applied aspects of

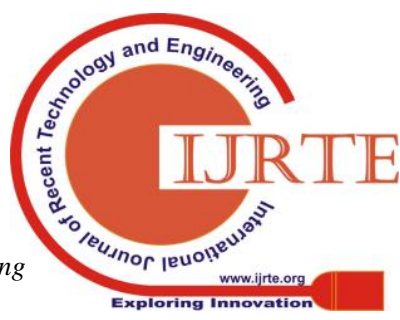


economic activity and sustainable development of enterprises, the measurement of economic expectations and the identification of strategic guidelines for economic growth in the context of globalization are detailed in the works of A. Turylo. M. Khvesyk, O. Shubalyi, N. Chebanova, V. Protsenko and others [7-10]. The concepts and approaches to digital management of corporate economic activity are presented in the works of S. Bruskin, S. Varna, E. Dorohan, T. Ketlin, L. Laberzh, L. Mikhov and O. Merenchuk [11-13]. However, the problematic of digitization of economic activity management and sustainable enterprise development requires in-depth study with taking into account multidimensionality and debatability of individual issues of business digitalization and the need to transform approaches to business administration.

\section{THE AIM OF THE PAPER}

The purpose of the research is studying the world experience and prerequisites for the enterprises transition to digital management and development of the digitalization reference model of economic activity and enterprise development management.

\section{RESULTS AND DISCUSSION}

The development of digital technologies (smart devices, big data analytics intellectual applications, Internet of Things, machine learning technologies, cognitive analytics services, etc.) changes the modern world and relationships within it. Trade, information sharing and ordinary human contacts are increasingly being transformed into the digital dimension with blurring the borders between states and making the idea of digital society creating and global digital economy actual [14].

The priority areas for society's digitalization, which are identified this year at the G20 Summit in Osaka, Japan, are:

- development of innovations for the digital economy;

- development of 5.0 human-centered society.

- maximal implementation of the artificial intelligence technologies potential and increasing of public confidence in such technologies;

- providing free data flow with simultaneous solution of problems are related to information security and intellectual property rights protection;

- digital divide overcoming and providing the digitalization of micro, small and medium-sized enterprises;

- development of smart cities [15].

According to the data research of Pricewaterhouse Coopers the increasing of the country's digitization level by $10 \%$ leads to increasing of GDP per capita by $0,75 \%$. The increasing of the same indicator by 10 points, according to the findings of the Academics resource, leads to decreasing of the unemployment rate by $1,02 \%$. In addition, according to the view of Accenture Company, the digital technologies can be used as impetus for faster economic development [16]. Therefore, the digitization should be considered as important driver of economic activity growth and sustainable development.

Released in early 2019, the World Economic Forum's research results show that $84 \%$ of «Internet of Things Technologies» can provide the achievement of the UN
Global Sustainable Development Goals [14]. We believe that business decisions and technologies which can provide quantitative and qualitative regeneration of the potential of all elements of the economic system, minimize the total costs, increase the population's standard of living, its social protection and preserve the environment, play the leading role in their achievement. The revival of the national economic system in new technical and technological and organizational format, increasing its competitiveness and providing sustainable development is possible under social relations digitization at all levels. The widespread use of digital technologies in public administration allows greater transparency of government and efficient e-government, and in the economics - providing its growth through expanding markets, including e-commerce environments, competition development, creating new conditions for business development, greater opportunities for consumers' interests satisfying. Accelerating of the scientific information exchange processes gives impetus to innovations.

Ukraine's progressive integration into the global economic space prioritizes reforms, including reforms which are related to digitalization of the economics, the spread of telecommunication technologies, and the providing development of high-tech business and innovation activity. Implementation of the Government's «Digital Economy and Society Development Concepts of Ukraine for 2018 - 2020» [17] and objectives' implementation of «Digital Agenda of Ukraine 2020» [18] will allow providing:

1) stimulating the economy and investments attracting;

2) forming the basis for digital transformation of economic sectors into competitive and efficient ones;

3) availability of «digital» technologies and tools;

4) creation of new opportunities for human capital realization, development of innovative, creative and «digital» industries and business, etc. (fig. 1).

\begin{tabular}{|l|l|l|}
\hline \multicolumn{2}{|c|}{ Digitization targets } & \multicolumn{2}{|c|}{ Ukrainian digital trends } & \\
\hline$\checkmark$ Equality of personalized & $\checkmark$ Information (data sets) is a & $\checkmark$ Creation of digital \\
access. & major source of & infrastructure, optimization \\
$\checkmark$ & of infocommunications. \\
sustainable development & $\checkmark$ Development of the & $\checkmark$ Economic activity \\
goals. & Internet of Things sphere. & increasing. \\
$\checkmark$ Digital transformation of & $\checkmark$ Digital transformation of & $\checkmark$ Competitiveness \\
economic spheres and & businesses and industries. & increasing. \\
sectors as a tool for & $\checkmark$ Dissemination of business & $\checkmark$ Innovation and \\
economic growth. & models of shared use & investment development. \\
$\checkmark$ Development of national & economy, which operates on & $\checkmark$ Corruption overcoming. \\
information content. & the base of digital & $\checkmark$ New opportunities for \\
$\checkmark$ European integration and & technologies. & effective realization of \\
international cooperation. & $\checkmark$ Virtualization of physical & human capital. \\
$\checkmark$ Standardization and & infrastructure IT-systems and & $\checkmark$ The social protection. \\
interoperability of digital & transition to service models. & $\checkmark$ Modernization of \\
transformation. & $\checkmark$ Use of artificial & security systems at all levels: \\
$\checkmark$ Increasing the level of & intelligence. & - Financial security; \\
confidence and security. & $\checkmark$ Digital platforms as & - Ecological safety; \\
$\checkmark$ Digitalization as an & sources of value formation. & - Cybersecurity. \\
object of focal and & & $\checkmark$ Providing the sustainable \\
integrated state & & development goals \\
administration & & achievement. \\
\hline
\end{tabular}

Fig. 1. Opportunities and results of «Digital Agenda of Ukraine» goals realization 
Digitalization leads to the emergence of new formats of doing business and, accordingly, requires the formation of new approaches to enterprise management, its activity and development, which allow forming their own ecosystem of information and communication interaction with different stakeholders, which is based on partnership, client-orientation, innovativeness and synergy. Currently, according to McKinsey consultants [6; 13], most managers don't have holistic view of digitalization. Taking into account that it is almost instantaneous, free and seamless ability to connect people, devices and physical objects anywhere, experts predict connecting to the network of about 20 billion devices by 2025, the urgency of much more powerful data analytics (because of the ability to get them quickly from a variety of devices and the growth of data volume), as well as the expansion of business processes and management decisions automation.

It is expedient to study the international experience of conceptualization and practice of enterprises' successful transition to their economic activity efficiency digital management, increasing of business activity and economic growth under the globalization for providing the efficiency of enterprise management digitalization. The arguments and developments of J. Westerman, E. McCaffy, and D. Bonnie in [4] are relevant in this context. Scientists develop the conceptual framework for digital transformation of business management and identified three areas of activity for the digital technologies implementation on the base of the results of large companies (with annual turnover of up to $\$ 1$ billion) managers' survey from 15 world countries, each of these areas integrates three groups of digital transformation tasks:

1) customer experience improving: customer's understanding; use of electronic gadgets and programs (top line growth); customer touch points creating;

2) operational process transformation: digital automation (process digitization); worker enablement virtualization; optimization of performance management;

3) business models transformation: digitally business modification; creating of new digital business; digital globalization.

The implementation of specific management actions in certain areas of digital transformation requires the identification and rethinking of forms, trends, methods and technologies of digital, innovative policies and relevant corporate culture, high level of which is necessary for reliable communication between all links in the form of management for fast changes application and enterprise's digital ecosystem forming. Its creation is impossible without modernization of the management information system of the enterprise, its organizational structure and all business processes with taking into account the digital transformation of updated values, priorities and key points. Priority vectors of digital transformations are presented in Table-I.

Modernization of the enterprise's management system and its transformation into a «digit» should be done in few stages. These stages are:

- monitoring new technologies, assessment of their effect on prospects of economic activity intensification and enterprise development and identifying opportunities for digital adaptation to changes;

- identifying priority areas of digitalization and development of appropriate measures for its implementation on each of them;

Table-I: Vectors of digitalization of enterprise's business process management

\begin{tabular}{|c|c|}
\hline Vector & Vectors' characteristic \\
\hline $\begin{array}{l}\text { Omnicanality of } \\
\text { customer service }\end{array}$ & $\begin{array}{l}\text { The necessity to use the maximum number of } \\
\text { communication channels with customers. The } \\
\text { digital customer service system must incorporate } \\
\text { the tools of adaptability, variability, scoring, } \\
\text { analytics and forecasting, it allows providing } \\
\text { prompt and easy service. }\end{array}$ \\
\hline $\begin{array}{l}\text { Infrastructure, } \\
\text { partnership, } \\
\text { collaboration }\end{array}$ & $\begin{array}{l}\text { Partnering, collaborating and integrating with } \\
\text { other companies or services opens up } \\
\text { opportunities for business development, } \\
\text { innovation and scaling, regardless of location. }\end{array}$ \\
\hline $\begin{array}{l}\text { Cross-functionality } \\
\text { of digital databases }\end{array}$ & $\begin{array}{l}\text { Creating client database allows operating } \\
\text { information about the client in order to model his } \\
\text { behavior, demand forecasting, formation of } \\
\text { personal priorities and appropriate adaptation of } \\
\text { his own products and services, with the least time } \\
\text { and labor. }\end{array}$ \\
\hline $\begin{array}{l}\text { Innovations and } \\
\text { investments }\end{array}$ & $\begin{array}{l}\text { Modern methods of project analysis and } \\
\text { management allow active search and approving } \\
\text { new trends of business development, innovative } \\
\text { goods and solutions. The innovative search } \\
\text { effectiveness determines the possibility and } \\
\text { expedience of real investment. }\end{array}$ \\
\hline $\begin{array}{l}\text { Data protection } \\
\text { (Cybersecurity) }\end{array}$ & $\begin{array}{l}\text { The important parameter for digital } \\
\text { communication and electronic business models is } \\
\text { users' confidence. It is necessary to identify the } \\
\text { existing risks, to implement secure information } \\
\text { and communication systems, infrastructure and } \\
\text { platforms, to provide appropriate consulting and } \\
\text { technological support to stakeholders in order to } \\
\text { protect their own commercial information and } \\
\text { personalized customer base. }\end{array}$ \\
\hline $\begin{array}{l}\text { Standardization } \\
\text { and } \\
\text { interoperability }\end{array}$ & $\begin{array}{l}\text { Harmonization of standards and technical } \\
\text { regulations solves the problem of data } \\
\text { compatibility and rapid flow to operational } \\
\text { control centers, which allows gaining autonomy } \\
\text { from other entities and protect against market } \\
\text { conditions changes. }\end{array}$ \\
\hline $\begin{array}{l}\text { The value of the } \\
\text { product }\end{array}$ & $\begin{array}{l}\text { Digitalization is value stimulus e of the product } \\
\text { from stakeholders' point of view. Digital } \\
\text { innovations give consumers the prerogative of } \\
\text { creating and commercializing value according to } \\
\text { size, scale and speed. Remote mode } \\
\text { communication possibility, round-the-clock } \\
\text { service support and ordering the product or } \\
\text { service significantly increase the value of the } \\
\text { product from the stakeholders' point of view and } \\
\text { minimize the company's capital expenditures. }\end{array}$ \\
\hline $\begin{array}{l}\text { Professional } \\
\text { competencies }\end{array}$ & $\begin{array}{l}\text { For successful digital business modernization, it } \\
\text { is very important to qualitatively motivate staff } \\
\text { and prepare them for innovations } \\
\text { implementation, because of the approach to } \\
\text { doing business is changed radically and the } \\
\text { company changes outdated marketing model to } \\
\text { the customer-centric system. Both employees } \\
\text { and management must be prepared for } \\
\text { continuous development, training and raising the } \\
\text { level of their skills. Digitalization creates new } \\
\text { staffing units with relevant competencies, which } \\
\text { is the key to human capital development. }\end{array}$ \\
\hline
\end{tabular}

- minimizing restrictions (financial, legal, technical, technological, personnel, environmental, infrastructure, security, etc.) and risks of business relationships forming and the ability to respond to business processes in real time;

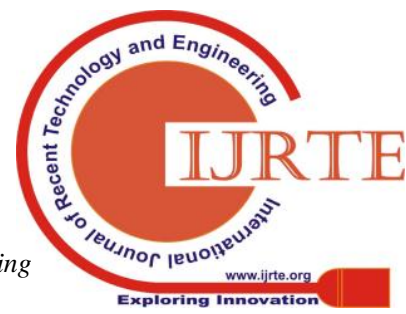


- integration of digital initiatives which are focused on the prospect of positive effects and development of the digitalization strategy;

- assessment of possible digitalization effect, adjustment of the chosen strategy and determining future priorities.

The applied artificial intelligence is the most effective digital management transformation technology; it bases on big data tools and allows visualization, cross-cutting planning, modeling and correction of business process management in real time. In addition, this technology, by integrating with analytics applications and services for work with smart devices, hybrid networks and other components of the digital world, allows optimizing business processes management infrastructure and provides the creation of digital platforms for the accumulation of information, its analytical processing and transmission for decisions making.

On the base of above-mentioned, we propose the reference model of digitalization of economic activity management and enterprise development (fig. 2), which provides the creation in one management system loop of information, analytical and management infrastructure in the form of appropriate platforms, and bases on the integration of a large number of functional and specialized and information and communication technologies which allow providing comprehensive solution of digitalization tasks of the individual business processes management processes and enterprise in general.

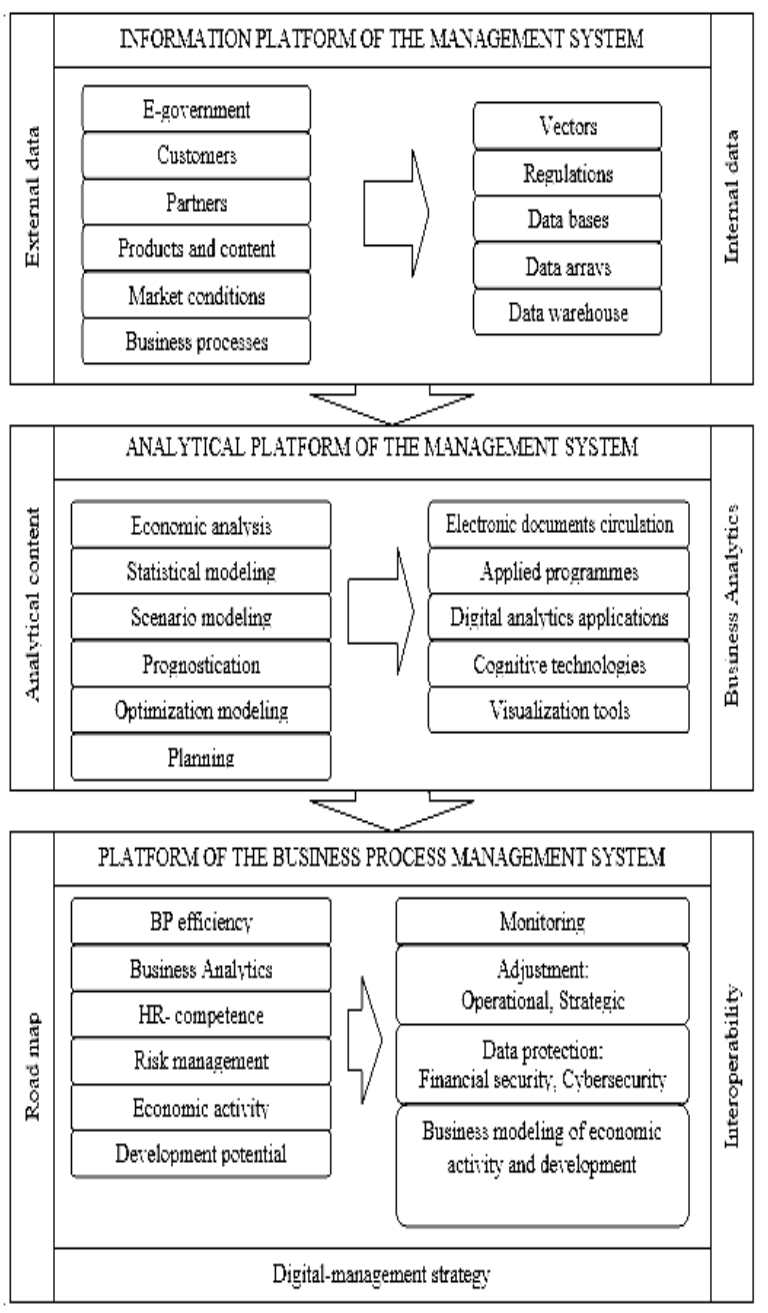

Fig. 2. Reference model of digitalization of economic activity management and enterprise development
The model operation mechanism is based on the use of freely disseminated information content (social networks, Internet resources, market information, etc.), own databases (in particular, client base), open software of analytical platform and integration platform of business process management which implements:

- data integration technology which provides consistent sharing of data which are produced by information systems, despite the fact that their own data structures were designed independently of one another, didn't contain fully information for solving complex problems as a whole, and they were not available to other information systems;

- digital applications integration technology which provides consistent sharing of integrated system functions, even though their functionalities were also independently designed, didn't include fully sets of functions which were needed for solving complex problems as a whole and they were not available to other information systems.

The implementation of the proposed approach to the digitalization of economic activity management and enterprise development provides unquestionable advantages in the form of: increased productivity through the digitalization of business processes; improving the management efficiency; transparency, simplicity and timeliness of interaction with stakeholders at all levels of management; acceleration of automation of production processes; expansion of production selling channels; opportunities to use of world markets.

\section{CONCLUSION}

The results of the study show that with taking into account the current trends of globalization and information systems and digital technologies development, the today priority task is creating the favorable environment for the digitalization of public relations in all spheres. It is noted that business administration digitalization is driver of economic activity growth and sustainable development of business entities. It is established that the implementation of priority targets of digitalization provides digital infrastructure optimization of management and infocommunications, modernization of security systems, creation of business entities ecosystems, their competitiveness increasing, economic activity stimulation and sustainable development goals achievement.

It is proved that the implementation effectiveness of management actions and measures for enterprise's management digitalization, its activity and development depends on the selected digital transformation technologies, the possibility of forming information arrays of relevant data, their analytical processing and presentation for making certain decisions in real time. The reference digitalization model of economic activity management and enterprise's development is elaborated, the distinctive feature of which is the integration in one management loop of three platforms (information, analytical and management); it allows obtaining the synergistic effect of the management process digital transformation at all its levels.

\section{Published By:}




\section{REFERENCES}

1. N. Colin, A. Landier, P. Mohnen, et al., "The digital economy", Notes du conseil d'analyse économique, vol. 26, pp. 1-12, 2015. Available: https://cairn-int.info/article-E_NCAE_026_-0001-the-dig ital-economy.htm

2. V.I. Liashenko, O.S. Vyshnevskyi, Tsyfrova modernizatsiia ekonomiky Ukrainy yak mozhlyvist proryvnoho rozvytku [Digital modernisation of Ukraine's economy as an opportunity for breakthrough development]. Kyiv: NAS of Ukraine, The Economy of Industry Institute, 2018. (in Ukrainian)

3. L. Andersson, L. Van der Heyde, "Directing Digitalisation - Guidelines for Boards and Executives. An INSEAD and this fluid world Collaboration". Available: http://www.thisfluidworld.com/wp-content/ uploads/2017/02/Corporate-governance-February-2017.p df

4. G. Westerman, D. Bonnet, A. McAfee. Leading digital: Turning technology into business transformation. Harvard Business Press, 2014.

5. L. Ligonenko, A. Khripko, A. Domanskii, "Zmist ta mehanizm formuvannya strategiyi didzhitalizaciyi $\mathrm{v}$ biznes-organizaciyah" ["The content and mechanism of forming a strategy of digitalization in business organizations,"] International Scientific Journal "Internauka", No. 22, 2018. [Online]. Available: https://www.inter-nauka.com/

uploads/public/15464416163127.pdf. [Accessed October 21, 2019]. (in Ukrainian)

6. J. Bloomberg, "Digitization, Digitalization, And Digital Transformation: Confuse Them At Your Peril". Available: https://www.forbes.com/sites/ jasonbloomberg/2018/04/29/ digitizationdigitalizationand-digital-transformation-confuse-them-atyour-peril/\#1e1fe3d02f2c

7. A.M. Turylo, I.S. Vcherashnya, "Teoretiko-metodichni pidhodi do viznachennya ponyattya "Ekonomichna aktivnist pidpriyemstva"" ["Theoretical and methodological approaches to the definition of the concept "Economic activity of the enterprise","] Finance of Ukraine, No. 10., pp. 79-84, 2011. (in Ukrainian)

8. M.A. Khvesyk, A.M. Shubalyy, "Suchasna paradigma stalogo rozvitku v umovah globalizaciyi" ["The modern paradigm of sustainable development under globalization,"] Economics of environmental management and protection of the environment, No. 3 ., pp. 4-13, 2011. (in Ukrainian)

9. O. Davydova, N. Chebanova, N. Kashchena, et al., "Economic activity of enterprises: methodical aspects of assessment" SHS Web of Conferences, Vol. 67, 2019. [Online].

https://www.shs-conferences.org/articles/ shsconf/abs/2019/08/

shsconf_NTI-UkrSURT2019_06012/shsconf_NTI-UkrS URT 2019_06012.html. [Accessed October 17, 2019]. (in English)

10. T.A. Staverska, "Viznachennya strategichnih prioritetiv zabezpechennya stalogo rozvitku torgovelnoyi galuzi $v$ umovah krizi" ["Defining strategic priorities for ensuring the sustainable development of the trading industry in a crisis,"] Financial mechanisms of crisis management: current realities and strategic orientations. Kharkiv, Ivanchenko I.S., 2018. (in Ukrainian)

11.L.I. Mikhov, O.M. Merenchuk, Ye.V. Dorohan, "Tsyfrove upravlinnia rezultatyvnistiu ekonomichnoi diialnosti korporatsii" ["Digital governance of the results of economic activities of corporations,"] Bulletin of Berdyansk University of Management and Business, No. 2(42), pp. 54-59, 2018. (in Ukrainian)
12.S.N. Bruskin, "Metody i instrumenty prodvinutoj biznes-analitiki dlya korporativnyh informacionno-analiticheskih sistem $\mathrm{v}$ epohu cifrovoj transformacii" ["Methods and tools of advanced business analytics for corporate information and analytics systems in the digital transformation era,"] International scientific journal "Modern Information Technologies and IT Education", Vol. 12, No. 3-1, pp. 234-239, 2016. (in Ukrainian)

13. T. Catlin, L. LaBerge, S. Varney, "Digital strategy: The four fights you have to win". Available: https://www.mckinsey.com/

-functions/mckinsey-digital/our-insights/digital-strategy-t he-four-fights-you-have-to-win

14. A. Dzhun, "Towards a digital society: how to waste Ukraine with time". Available: http://cpis.org.ua/na-shlyahu-do-czifrovogo-suspilstva-ya k- ukra\%D1\%97ni-ne-vtratiti-chas/

15. "G20 Summit 2019 Themes Ensures Sustainable Development". http://abclive.in/g20-summit-2019-themes

16. "Digital Transformation Readiness". Available: https://www.imena.ua/blog/digital-transformation-readin ess

17. "About approval of the Concept of development of digital economy and society of Ukraine for 2018-2020 and the approval of the plan of actions for its implementation". Available: https://kmu.gov.ua/ua/npas/proshvalennya-koncepciyi-rozvitku-cifrovoyi-ekonomiki-tas uspilstva-ukrayini-na-20182020-roki-ta-zatverdzhennyaplanu-zahodiv-shodo-yiyi-realizaciyi

18. "Digital agenda of Ukraine-2020 ("Digital agenda"-2020) Conceptual framework (version 1.0). Priority areas, initiatives, projects of digitalisation of Ukraine until 2020". Available: https://ucci.org.ua/uploads/files/ 58e78ee3c3922.pdf

\section{AUTHORS PROFILE}

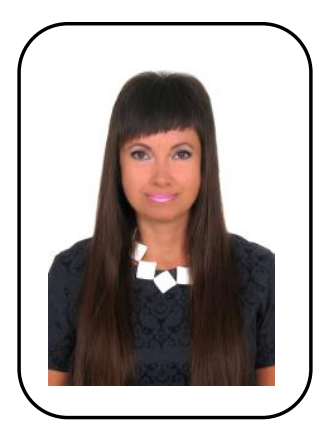

Oksana Davydova - Doctor of Economics, professor, professor of the Department of Hotel and Restaurant Business at Kharkiv State University of Food Technology and Trade (Kharkiv, Ukraine).

ORCID ID: 0000-0003-3045-9464.

Education: Kharkiv Institute of Public Catering (1994), Kharkiv, Ukraine. O. Davydova has more than 280 scientific papers, including 15 monographs, and 8 textbooks. The main scientific interests of O. Davydova are: innovative management of the development of enterprises of the hotel and restaurant industry, quality and safety management of products an services of the hotel and restaurant industry, scientific substantiation and development of innovative technologies in the enterprises of the hospitality industry. O. Davydova has developed such academic subjects: "Quality Management of Products and Services in Hotel and Restaurant Business", "International Standards of Service in the Accommodation Facilities", "Modeling of Priority Services of Hotel and Restaurant Businesses". 


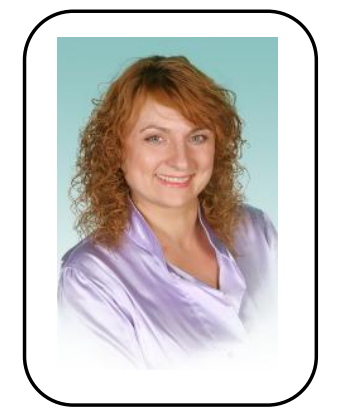

Nataliia Kashchena - Candidate of Economics, associate professor, professor of the Department of Finance, Analysis and Insurance at Kharkiv State University of Food Technology and Trade (Kharkiv, Ukraine).

ORCID ID: 0000-0001-7069-8860.

Education: Kharkiv Institute of Public Catering (1991), Kharkiv, Ukraine. N. Kashchena has more than 250 scientific papers, including 14 monographs, and 15 textbooks. N. Kashchena supervises the scientific work of Ph.D. students. The main scientific interests of N. Kashchena are: theoretical and methodological aspects of the analysis of the efficiency of functioning and sustainable economic development of the subjects of the hotel and restaurant business and trade. N. Kashchena has developed such academic subjects: "Analysis of Economic Activity", "Financial Diagnostics", "Valuation of Business Value".

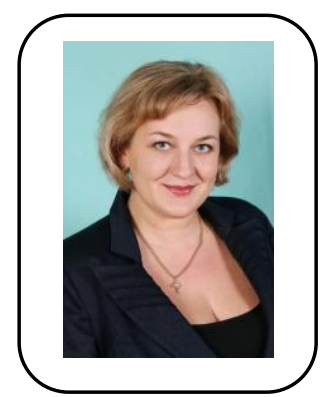

Tetiana Staverska - Candidate of Economics, associate professor, associate professor of the Department of Finance, Analysis and Insurance at Kharkiv State University of Food Technology and Trade (Kharkiv, Ukraine).

ORCID ID: 0000-0001-8417-2982.

Education: Kharkiv State Academy of Food Technology and Trade (1998), Kharkiv, Ukraine. T. Staverska has more than 130 scientific papers, including 7 monographs and 15 textbooks. T. Staverska supervises the scientific work of Ph.D. students. The main scientific interests of T. Staverska are: financial prognostication and planning, financial security, financial and economic mechanics of steel security. T. Staverska has developed such academic subjects: "Financial Planning and Forecasting in Enterprises and Financial Institutions", "Finance, Money and Credit", "Budgeting of Business Entities".

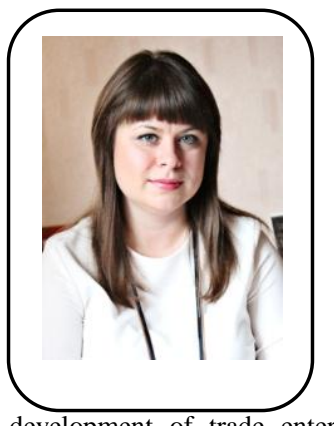

Hanna Chmil - Candidate of Economics, associate professor, associate professor of the Department of Marketing and Commercial Activities at Kharkiv State University of Food Technology and Trade (Kharkiv, Ukraine).

ORCID ID: 0000-0002-3703-9940.

Education: Kharkiv State University of Food Technology and Trade (2010), Kharkiv, Ukraine. H. Chmil has more than 70 scientific papers, including 7 monographs, and 1 textbooks. The main scientific interests of H. Chmil are: efficiency and sustainable development of trade enterprises, hospitality industry on the basis of marketing. H. Chmil has developed such academic subjects: "Marketing", "Marketing Performance Management". 